\section{Alpine Fault of New Zealand and Gondwanaland reconstruction}

GRIFFITHS $^{1,2}$ has proposed two reassemblies of Gondwana fragments in the south-west Pacific, including New Zealand and the surrounding complex of submarine ridges and plateaux. Both recontructions are based essentially on bathymetric data, the salient difference in the later, revised version being a $250 \mathrm{~km}$ eastward displacement of Antarctica relative to Australia, to create space for the newly incorporated South Tasman Rise and East Tasman Plateau.

In general terms, Griffiths's reconstructions are feasible, and, as they agree in many respects with my own earlier schematic reconstruction ${ }^{3}$ of the region, I do not wish to criticise them except on one important issue. This concerns the nature of the Alpine Fault trace in the reconstituted Gondwana landmass. In his original reconstruction, Griffiths ${ }^{1}$ achieves a close fit of south-west Pacific continental and quasi-continental crustal segments by introducing a sharp deflection-through some $70^{\circ}$-in the line supposedly followed by the Alpine Fault. In his revised version ${ }^{2}$, the Alpine Fault trace becomes even more complex and describes a neat parabolic curve with bifurcating and reconverging branches. Neither interpretation is consistent with the known geometry and tectonic behaviour of the Alpine Fault, and, in my opinion, both embody misconceptions arising from a failure to appreciate that dislocation along the Alpine Fault has been accompanied by substantial deformation of the New Zealand crustal segment.

As I have attempted to demonstrate elsewhere ${ }^{3}$, the distinctive NE-SW trend of the New Zealand landmass and its congruent regional geological strike both relate to New Zealand's evolution, since late Cretaceous times, along the interface between two moving crustal plates. West of New Zealand, the opening of the Tasman Sea has been attributed ${ }^{4}$ to late Cretaceous and Palaeocene activity of a NW-SE trans-Tasman spreading axis (perhaps an initial westward prolongation of the still active Pacific-Antarctic Ridge), that brought about a rapid north-eastward migration of the continental and quasi-continental crust of Lord Howe Rise and Norfolk Ridge. To the south and east of New Zealand, extension of the south-western Pacific Basin commenced simultaneously ${ }^{5}$, and Campbell Plateau and Chatham Risetheir free movement to the north-west obstructed by Lord Howe Rise and Norfolk Ridge-were forced northward at a somewhat slower rate.

These differential movements produced, among other effects, large scale sigmoidal flexuring of the broad belt of Palaeozoic and Mesozoic greywacke formations that had accumulated along the margin of Gondwanaland, in the so-called New Zealand Geosyncline ${ }^{6}$. The development of a complex system of NE-SW major shear fractures, the best known of which is the Alpine Fault, marked the
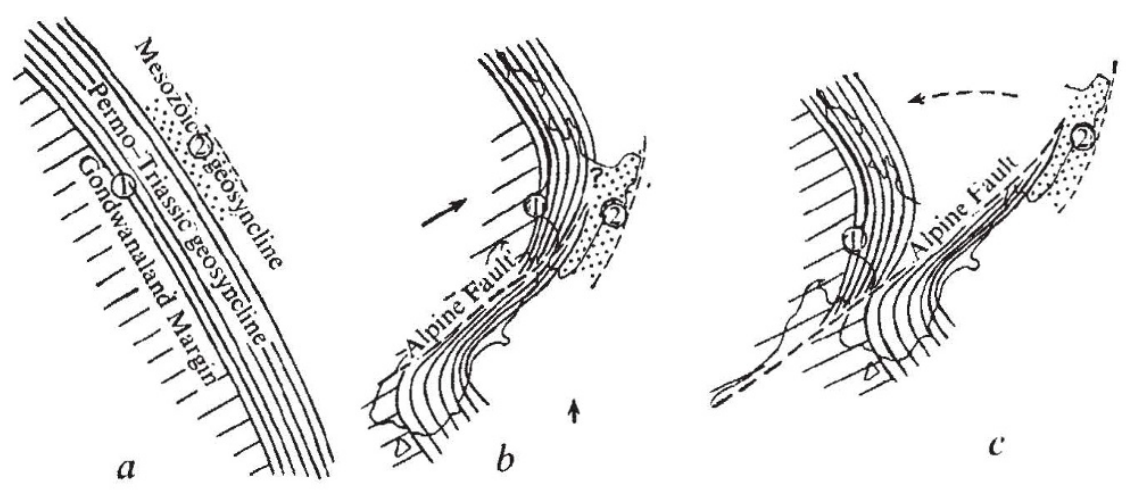

Fig. 1 Schematic reconstruction of the New Zealand region. $a$, Postulated distribution of linear geosynclinal belts along the eastern margin of Gondwanaland Numerals represent approximate sites of Egmont (1) and Hawke Bay (2). b, Present day New Zealand structure. Trend and length of arrows indicate direction and rate of Cainozoic crustal movements. $c$, Spurious Gondwanaland reconstruction (compare Griffiths $^{1,2}$ ) achieved by simple reversal of the Alpine Fault displacement and realignment of the Permo-Triassic geosynclinal belt. Note that artificial rotation of the Alpine Fault (broken arrow) places Hawke Bay some $500 \mathrm{~km}$ north of Egmont, and duplicates a section of the Permo-Triassic geosyncline. culmination of this flexuring. Within the vicinity of New Zealand, the original course of the peripheral geosyncline can legitimately be supposed to have been more or less linear, and it is essential that, in any reassembly of crustal fragments, compensation be made for the crustal distortion that followed the disruption of Gondwanaland. Figure 1 demonstrates that, in such reconstructions, it is not sufficient merely to postulate reverse displacement of crustal segments by the amount of obvious fault offset. Admittedly, the structural unravelling of intensely deformed areas is not easy, but I would suggest that allowance for crustal distortion, as well as dislocation, in the New Zealand region would simplify and rationalise the form of the Alpine Fault trace in reconstructions such as those of Griffiths.

\section{David J. Cullen \\ New Zealand Oceanographic Institute, Department of Scientific and Industrial Research, \\ PO Box 8009, Wellington, New Zealand}

1 Griffiths, J. R., Nature, 234, 203 (1971).

2 Griffiths, J. R., Nature, 249, 336 (1974).

3 Cullen, D. J., NZ J. Geol. Geophys., 13, 7 (1970).

4 Hayes, D. E., and Ringis, J., Nature, 243, 454 (1973).

5 Heirtzler, J. R., Dickson, G. O., Herron, E. M., Pitman, W. C., and Le Pichon, X., J. geophys. Res., 73, 2119 (1968). 6 Fleming, C. A., Tuatara, 10, 53 (1962).

Dr GrifFITHS REPLIES-Cullen's main point seems to be that the Alpine Fault is not the only deformation of New Zealand which occurred during seafloor spreading and that it is therefore insufficient simply to reverse the observed $480 \mathrm{~km}$ offset in reconstructions. I have, however, always accepted this point; it is not explicitly stated but is quite obvious from the diagrams in my 1971 article (Nature, 234, 203-207). I have suggested (Nature, 235, 83-86; 1972) that the total offset of the New Zealand Geosyncline is some $1,200 \mathrm{~km}$, which is partly taken up by the Alpine Fault, and the rest by "bending and stretching of the geosynclinal axis". Though detailed structure is not shown, the general concept is quite clear from the figures. I have also referred to the 'Alpine Fault Zone' as distinct from the specific fault (Nature, 249, 336; 1974); it is the former which is indicated on the figure. I have in preparation an enlarged version of my Alpine Fault model, but as it involves over $\mathbf{3 0}$ dia- 